\title{
Where in the value chain are we losing the most food? The case of wheat in Jordan
}

\author{
Basel F. Y. Khader ${ }^{1} \cdot$ Yigezu A. Yigezu ${ }^{2}$ (1) $\cdot$ Mahmud A. Duwayri $^{3} \cdot$ Abdul Aziz Niane $^{4} \cdot$ Kamil Shideed $^{2}$
}

Received: 25 April 2018 / Accepted: 23 July 2019 / Published online: 16 August 2019

(C) The Author(s) 2019

\begin{abstract}
Efforts to increase global food supply through increased productivity and intensity of cropping are well documented. However, the literature on measurement of food losses and wastage and techniques to reduce them is scanty. This study aimed at providing credible evidence on the levels of food losses and wastage at each node along the entire wheat value chain in Jordan - from farm to fork. The "life cycle of food" approach, along with standard protocols developed in line with international initiatives led by the World Resources Institute (WRI) were used for physical measurements and estimation of losses at each node. Our results show that $34 \%$ of the total wheat supply in Jordan (both from local production and imports) is lost or wasted - costing the country about US $\$ 105$ million per year, which is also associated with high levels of losses in natural resources. We found that postharvest losses are more important in Jordan where, at a level of $12.95 \%$, wastage during consumption by households ranks first. Households reported that $67 \%$ of the household food waste was fed to animals. This means Jordan is losing $43 \%$ and $48 \%$ respectively of total protein and energy for every 1US\$ spent on bread that is fed to animals instead of barley. These results call for a concerted effort by individuals, civic societies, NGOs and the government towards awareness raising and measures targeting reduction of wastage, especially during consumption. The Government of Jordan has recently reviewed the subsidy on bread, raising hopes that it will reduce consumption losses.
\end{abstract}

Keywords Pre-harvest loss $\cdot$ Postharvest loss $\cdot$ Food waste $\cdot$ Bread $\cdot$ Wheat $\cdot$ Value chain

\section{Introduction}

Food security is one of the major challenges facing humanity today. According to the definition provided by the world food summit of 1996, food security exists "when all people at all times have access to sufficient safe nutritious food to maintain a healthy and active life" (WHO 2014). Rapid population growth in the face of a shrinking productive resource base,

Yigezu A. Yigezu

y.yigezu@cgiar.org

1 Department of Agriculture, Scientific Research Support Fund, Jordanian Ministry of Higher Education, P.O Box 2680, Amman, Jordan

2 International Center for Agricultural Research in the Dry Areas (ICARDA), PO Box 950764, Amman, Jordan

3 University of Jordan, P.O Box 11942, Amman, Jordan

4 International Center for Agricultural Research in the Dry Areas (ICARDA), Beirut, Lebanon including cultivatable land and irrigation water, makes the challenge increasingly difficult. World population is expected to reach 9.7 billion by 2050 (UN-DES 2017), which means there will be $33 \%$ more human mouths to feed, most of which will be in the poorest countries of the world (FA 2013). In order to meet the projected food demand in 2050, food supplies would need to increase by $60 \%$.

Food availability can be increased using one or a combination of the following approaches: i) increased production through area expansion; ii) increasing productivity per unit area through intensification (defined here as increased amounts of inputs per unit area); and iii) reduction of food loss and wastage from the field to the fork; (iv) increasing cropping intensity by using the same land to produce more than one crop a year. However, there is generally limited scope for expansion of arable lands and when it is possible, it comes at the expense of environmental health (Pardey 2011). Increasing productivity through intensification is therefore the major route that had been taken to address problems related to food security and considerable achievements have been recorded over the years. However, the 
potential of genetic improvements and improved agronomic practices in increasing productivity seems to be approaching the right tail of the sigmoid curve for agricultural productivity. For instance, the global average annual productivity growths in the three major crops (rice, maize, and wheat) have been much lower for the period 1990-2007 than that for the period 1960-1990 (Pardey 2011).

If the additional wheat demand by 2050 is to be met, wheat yields have to grow by $1.4 \%$ per year. This means breeders will need to increase average global wheat yield by $0.7 \%$ per year - a rate of progress that most breeding programs are struggling to achieve, and agronomists will have to achieve yield gains of another $0.7 \%$ (WHEAT 2016). Achieving these targets is even more challenging in the dry areas (including Jordan-which is the subject of this study) where agricultural production is highly constrained by water scarcity, moisture stress and drought, and land limitation and degradation. Therefore, a multifaceted approach involving the exploration and exploitation of the potential with other alternative options that will complement the additional food supply from genetic gains is essential if the goal of making adequate food available for the growing world population is ever to be met.

Reducing food losses and wastage is one such option, the potential of which needs to be explored and fully exploited. Based on estimates by the Food and Agriculture Organization of the United Nations (FAO), about 1.3 billion tons of food is globally wasted or lost per year (Gustavsson et al. 2011) with a total value of roughly $\$ 250-\$ 440$ per year per household (Wilson and Wilson 2009). Reduction of these losses would lead to a substantial increase in the amount of food available for human consumption and an increase in global food security (WB 2008; Trostle 2010). To achieve the goals of food security, we must reduce food losses throughout the supply chain for each crop. About 1.2-2 billion metric tonnes (30$50 \%$ of global production) is estimated to be lost every year which has the potential to provide $60-100 \%$ more food for consumption. This implies wastage of 550 billion $\mathrm{m}^{3}$ of water and $1 \%$ to $1.5 \%$ of global energy (Fox and Fimeche 2013).

Around 25 million tons of wheat is estimated to be lost post-harvest, out of which, $46 \%$ is believed to occur in developing countries (Baloch 1999). Generally, developing countries suffer higher levels of food losses (both in quantity and quality) than developed countries - mainly due to widespread use of traditional methods of harvesting, handling, processing and storage of agricultural products.

Food waste remains a relatively unexplored topic especially in the Middle East in general and in Jordan in particular (Obeidate et al. 2015). While there are rough estimates of the total global food losses (Fox and Fimeche 2013), most of them are either based on expert opinions and hence vary widely or they do not provide clear explanation on what was being estimated, how the estimation was made, and when (Kitinoja and Kader 2015). More importantly, only a few of them provide detailed breakdown in terms of where in the value chains exactly these losses are taking place. Food losses and waste can happen at different nodes of the value chain, namely: in the field during the growing period of the crop, at harvest (due to timing, method and efficiency related problems), at storage, transport, processing, marketing, and consumption. Having estimates of losses at each of these nodes will be highly valuable for policy making and targeting and prioritizing interventions.

Some studies (see for example, Jones et al. 2018; Goldsmith et al. 2015; Sattar et al. 2015; Baloch et al. 1994; Sawhney 1988) have followed scientifically defendable protocols, approaches and established theories for measuring and analyzing losses. However, they are limited to only certain nodes or specific aspects of losses in a given node along the value chain, failing to provide the whole picture in one or more value chains. Recently, a number of studies that synthesize existing information from past studies on postharvest losses for horticultural crops (including meta-analyses) have characterized food losses (Gustavsson et al. 2011; Lipiniski 2013; Affognon et al. 2015). The resulting estimates are widely disparate, and the UN FAO SAVE FOOD Initiative currently uses the figures of $45 \%$ for losses of both roots/tuber crops and fruits/vegetables. Many international development authorities (e.g. the UNFAO, the World Bank and USAID) and journal articles citing primary works typically quote a general range of 30 to $50 \%$ postharvest losses. However, the sources of these estimates are not known (Kitinoja and Kader 2015).

Food losses are usually the unintended results of technical and management limitations in agricultural production processes, infrastructure, storage, transport, packaging, and/or marketing while food waste refers to food that is of good quality and fit for consumption but does not get consumed because it is discarded-either before or after it is left to spoil (Lipiniski 2013). Food waste typically, but not exclusively, takes place at the retail and consumption stages in the food value chain. It is usually the result of negligence or a conscious decision to throw food away. In terms of their nature, losses and wastes can be broadly classified into two: quantitative and qualitative. Losses can also be classified in terms of their utilization/disposal which includes the yield gap between what farmers are actually producing/harvesting and what was possible if they were to use optimal management practices; total loss (food going to landfills); diverted use (food used as feed, or for compost or biogas production and hence is no more available for direct human consumption); or food utilized sub-optimally (without capturing its full consumption and/or nutritional value(s)). Losses depend on several factors such as environmental conditions, method and duration of 
storage, methods of processing and the inherent features of the different nodes along the value chain in a given environment.

This paper attempts to quantify and provide credible evidence on the levels of food losses and wastage at each node along the entire wheat value chain - from farm to fork in Jordan. By so doing, the paper helps to prioritize investment in research into loss reduction interventions including the development and utilization of appropriate and advanced techniques, policy and institutional changes and awareness raising among citizens. This study should not be considered as a value chain analysis, but simply a study that attempts to measure food loss or wastage at each node of the wheat value chain. For the purpose of our study, we define food loss and waste as wheat-based food that becomes unavailable for direct human consumption in Jordan after it is imported or during and after local production. While we are aware of the ongoing debate about whether food put to alternative uses (such as animal feed) is a waste or not (see for example Bellemare et al. 2017), there does not seem to be a consensus. Therefore, in this paper, we have decided to measure it and present it as waste and let the reader decide on whether to include it in the total loss or not. Moreover, we provide detailed comparison on the opportunity cost of using processed wheat (particularly bread) for feed as opposed to barley, which is the main feed item in Jordan and show the implications in efficiency in terms of calorie and protein intakes of the animals.

Given the limited time and resources that were available, this study does not include all types of possible losses/wastes. Some of the losses/wastes may not even be relevant to the study area. For example, sprouting and weathering are more relevant in high rainfall and humid areas than in the dry areas covered in our study. Specifically, this study is limited to the measurement of quantitative food losses and wastes at the different nodes of the wheat value chain in Jordan including losses that were not realized due to technical and management-related shortcomings as well as food inadvertently or negligently wasted during processing, marketing and consumption.

Protocols developed in line with international initiatives (Hanson et al. 2016) were used for physical measurements and estimation of losses during pre-harvest, harvest, storage, transport, and consumption at restaurants. Surveys and company records were used to collect data that were used for estimation of losses during processing, marketing, and consumption at households. Micro-level estimates were aggregated to national levels using area and population weights. The findings of this study are expected to be useful to policy makers, donors, researchers and community-based organizations that work in the areas of food security and nutrition. The results are also expected to stir useful discussions nationally, regionally and globally, in terms of raising awareness as well as priority setting for research investment.

\section{The wheat sector in Jordan}

Jordan is generally a net food importer, despite selfsufficiency in a few food items such as olives, olive oil, tomatoes, goat meat, fresh milk and eggs. The biggest gap between production and consumption is cereals, as Jordan produces only $3 \%$ and $3.6 \%$ of its total food needs in wheat and barley respectively (Badran et al. 2018). Price support policies for both inputs and outputs play a vital role in shaping the production system in the rainfed region of Jordan. The government price support system for encouraging production of field crops (mainly wheat and barley) has triggered a huge production process in areas that are not suitable for field crop production. On the one hand, this process has destroyed a major part of the fragile vegetative cover in the rangelands, and on the other, it has increased the livestock numbers, predominantly those of small ruminants. High supplementary feed costs encouraged by the government barley subsidies and falling forage availability are major constraints both on the profit margins of producers and in the competitiveness of their products at national and international markets. Twenty years of subsidy and ease of transport around the desert have encouraged the livestock industry to become dependent on barley, which accounted for $63 \%$ of feed costs for producers. Barley remains cheaper than any other alternative cereal such as maize (Sidahmed et al. 2012). However, a substantial amount of bread is also being used as animal feed (Khraishy and Beillard 2018).

Agricultural production, local or international transport, processing, storage and distribution is very sensitive to energy costs. Energy costs make up $15 \%$ to $22 \%$ of total food production costs in Jordan. Though it is still important to the country, the impact of energy costs on the wheat value chain in Jordan is believed to be relatively small because Jordan depends mainly on wheat imports (Badran et al. 2018). In 1996, the government implemented an economic adjustment program promoted by the IMF, which focused mainly on subsidy expenditures. Bread subsidies were particularly targeted since international wheat prices surged from $\$ 175$ to $\$ 280$ per ton in 1995. Within a few days, the price of bread and fodder more than doubled and consequently, the government introduced a compensation scheme to protect the poor. Unfortunately, the compensation was far from sufficient, and it was actually offset by price increases for dairy products. This was because fodder was a major input in dairy production (JIEW 2014). The general food subsidies were believed to be only marginally beneficial to the poor. After 1992, there was a 
shift to progressive cash transfers, which mainly targeted the unemployed and those not physically able to take up available jobs. The shift is said to have led to better consumption outcomes because of better targeting. This program would, apriori, have had a greater impact on poverty reduction than general food subsidies because targeting of the poor was quite successful (Seijaparova and Pellekaan 2004). However, by 2002, several other factors, including inflation, caused a significant portion of the non-poor population to get very close to the poverty line (JIEW 2014). To make it worse, the pressure from IMF to eliminate fuel subsidies caused the government to take an initiative to reduce them gradually over the period 2005-2008, which was followed by another round in 2012 (Badran et al. 2018).

Historically, bread subsides in Jordan were implemented through the subsidization of flour. For example, in 2017, the market price of wheat flour was about $\$ 332$ per metric ton (MT) while the size of the subsidy was approximately $\$ 71 /$ MT. Large variation in flour prices has reportedly fomented a black market and illegal practices including tax evasion (Khraishy and Beillard 2018). In 2017 Jordan allocated approximately $\$ 170$ million to a bread subsidy program. As of January 2018, the Jordanian government moved away from subsidizing the flour into cash transfers to targeted families and increased the price of subsidized bread. Therefore, large bakeries welcomed the Jordanian government's measure to lift flour subsidies because the reform is expected to help put an end to subsidized wheat flour leakages that distort the market. When the new policy is fully implemented, bakeries that traded/resold subsidized wheat flour are expected to drop out of the market (Khraishy and Beillard 2018).

\subsection{Description of the wheat value chain in Jordan}

With a 5-year average yield of $1.23 \mathrm{MT} / \mathrm{ha}$, total annual domestic production stands at 23,420 MT - enough to cover only a few weeks of national demand. Total wheat imports during the same period amounted to 794,000 MT. In the face of a growing population, water shortage, and declining land productivity, the share of domestic production in total national wheat supply in Jordan is getting smaller with time - making the country increasingly import dependent (Table 1).

With the few exceptions of those who store some wheat grain in their own facilities, most domestic farmers transport their produce to aggregation centers administered by agricultural co-operative societies (ACS). Then, the ACS sell part of the grain to the Ministry of Industry and Trade (MIT) for consumption and partly to the Ministry of Agriculture for use as seed in the next season. In 2014/15, the price of grain sold for consumption was 370 Jordanian Dinars (JD) per tonne while that of grain sold as seed was about $420 \mathrm{JD} /$ tonne ( $1 \mathrm{JD}=1.41 \mathrm{US}$ Dollars). In the most recent
(2015/2016) season, only 11,863 tonnes of locally produced wheat was delivered to two public silos.

Wheat imported into the country is first stored in the storage facility at the port city of Aqaba where there are 150 silos with a total capacity of 140 thousand tonnes. It is then transported by land to three inland public storage facilities with a total storage capacity of 465 thousand tonnes, namely: 1) Irbid where there are 150 silos with a total capacity of 140 thousand tonnes; 2) Russeifa which has total capacity of 130 thousand tonnes and which is divided into four concrete silos of 9.4-thousand-tonne capacity each and ten metal silos of 9.3thousand-tonne capacity each and; 3) Jowaydeh which contains 150 silos with a total capacity of 140 thousand tonnes. The average size of a typical silo in the country is 1300 tonnes. During the storage period, the minimum, average and maximum monthly ambient temperatures are usually $15^{\circ} \mathrm{C}, 32^{\circ} \mathrm{C}$ and $44^{\circ} \mathrm{C}$, respectively.

As locally produced wheat does not usually meet the minimum quality specifications, the silos always mix it with the imported wheat at a $10 \%$ to $90 \%$ ratio (the imported wheat constituting $90 \%$ of the mix) and store the mix as a single bulk with no quality differentiation. Usually, grain is stored in the silos for between 1 and 3 months with an average duration of 2 months. Out of the total wheat supply in the country, $82 \%$ is milled into flour. When wheat grain leaves the storage facilities, it is transported directly to grain mills. Jordan has a total of 16 wheat grain mills, 15 of which belong to the private sector while one (called Jwaydeh Mill) is public. The combined capacity of all 16 mills is about 120 tonnes $/ \mathrm{h}$.

There are around 2100 bakeries (all private) which get their flour supplies from the mills to produce many kinds of bread. Most (96\%) of the flour is used for the production of local bread called Khubz of different types where $75 \%$ (with high bran content and considered inferior in quality) is used to produce the common bread (locally called mowahad Khubz) which is sold at a highly subsidized price of $0.16 \mathrm{JD} \mathrm{kg}^{1} ; 15 \%$ (with slightly lower bran content) is used for the production of another type of common bread (locally called mohassan khubz), which is of a slightly higher quality and is sold at a price of $0.25 \mathrm{JD} / \mathrm{kg} ; 5 \%$ (first grade flour with very low bran) is used for the production of even higher qualities of bread (locally called sharkh and hamamand Khubz), which are sold at prices of $0.7 \mathrm{JD} / \mathrm{kg}$ and $1 \mathrm{JD} / \mathrm{kg}$ respectively. Four percent of the products of mills are used to produce pasta and semolina which are distributed in super markets. The remaining $1 \%$ is used to produce a wide variety of pastries, which are sold at a wide range of prices (1JD to $20 \mathrm{JD}$ ) depending on their kind and quality. Bakeries and pastry houses sell their products to households, grocery stores, and restaurants. The prices of

\footnotetext{
${ }^{1}$ As of January 2018 , the prices of mowahad and mohassan Khubz have been increased from 0.16 to $0.32 \mathrm{JD} / \mathrm{kg}$ and from 0.25 to $0.50 \mathrm{JD} / \mathrm{kg}$ respectively.
} 
Table 1 Wheat area, local production and wheat imports wheat (2014)

\begin{tabular}{|c|c|c|c|c|c|c|}
\hline Year & $\begin{array}{l}\text { Total area } \\
\text { planted to } \\
\text { wheat } \\
\left(000^{\prime} \text { ha }\right)\end{array}$ & $\begin{array}{l}\text { Total } \\
\text { harvested } \\
\text { wheat area } \\
\text { ('000 ha) }\end{array}$ & $\begin{array}{l}\text { Average } \\
\text { Yield from } \\
\text { harvested } \\
\text { area (tonne/ } \\
\text { ha) }\end{array}$ & $\begin{array}{l}\text { Total } \\
\text { wheat } \\
\text { production } \\
\text { ('000 } \\
\text { tonnes) }\end{array}$ & $\begin{array}{l}\text { Total } \\
\text { wheat } \\
\text { imports } \\
\text { ('000 } \\
\text { tonnes) }\end{array}$ & $\begin{array}{l}\text { Share of local } \\
\text { production in } \\
\text { total wheat } \\
\text { supply }(\%)\end{array}$ \\
\hline 1993 & 67.92 & 37.57 & 1.52 & 57.09 & 667.10 & $9 \%$ \\
\hline 1994 & 42.45 & 29.71 & 1.58 & 46.85 & 508.10 & $9 \%$ \\
\hline 1995 & 51.23 & 40.56 & 1.44 & 58.45 & 335.40 & $17 \%$ \\
\hline 1996 & 32.93 & 28.35 & 1.51 & 42.67 & 584.00 & $7 \%$ \\
\hline 1997 & 56.89 & 37.92 & 1.10 & 41.78 & 587.10 & $7 \%$ \\
\hline 1998 & 50.46 & 28.83 & 1.25 & 35.97 & 857.20 & $4 \%$ \\
\hline 1999 & 50.66 & 4.09 & 2.26 & 9.25 & 393.50 & $2 \%$ \\
\hline 2000 & 47.64 & 18.20 & 1.40 & 25.43 & 584.10 & $4 \%$ \\
\hline 2001 & 44.36 & 13.45 & 1.43 & 19.29 & 583.00 & $3 \%$ \\
\hline 2002 & 42.70 & 32.75 & 1.34 & 43.77 & 618.40 & $7 \%$ \\
\hline 2003 & 50.06 & 29.78 & 1.43 & 42.52 & 720.00 & $6 \%$ \\
\hline 2004 & 34.53 & 10.73 & 1.23 & 13.16 & 670.40 & $2 \%$ \\
\hline 2005 & 38.58 & 29.29 & 1.17 & 34.36 & 712.90 & $5 \%$ \\
\hline 2006 & 41.86 & 26.92 & 0.85 & 22.92 & 591.20 & $4 \%$ \\
\hline 2007 & 20.76 & 20.76 & 1.01 & 20.99 & $1,011.10$ & $2 \%$ \\
\hline 2008 & 24.80 & 12.46 & 0.63 & 7.83 & $1,065.80$ & $1 \%$ \\
\hline 2009 & 24.05 & 15.88 & 0.79 & 12.48 & 624.70 & $2 \%$ \\
\hline 2010 & 30.01 & 21.47 & 1.03 & 22.12 & 489.60 & $5 \%$ \\
\hline 2011 & 19.30 & 14.33 & 1.38 & 19.80 & $1,076.60$ & $2 \%$ \\
\hline 2012 & 21.30 & 15.50 & 1.24 & 19.20 & 906.30 & $2 \%$ \\
\hline 2013 & 26.24 & 21.38 & 1.33 & 28.51 & 833.40 & $3 \%$ \\
\hline 2014 & 26.68 & 23.02 & 1.19 & 27.45 & 949.67 & $3 \%$ \\
\hline 10-Year-Average & 27.36 & 20.10 & 1.06 & 21.57 & 729.68 & $3 \%$ \\
\hline 5-Year-Average & 24.70 & 19.14 & 1.23 & 23.42 & 794.74 & $3 \%$ \\
\hline
\end{tabular}

Source: Department of Statistics, Agricultural Report, Amman-Jordan, 2014 wheat products are controlled by the Ministry of Industry and Trade, and there are penalties for the discordant bakeries/retailers that are not adhering to the prices set by the Ministry. Figure 1 depicts the wheat value chain in Jordan.

\subsection{Food loss and wastage in the wheat value chain}

Pre and post-harvest food loss is defined as measurable qualitative and quantitative food loss along the value chain, starting at the time of harvest up to its consumption or other

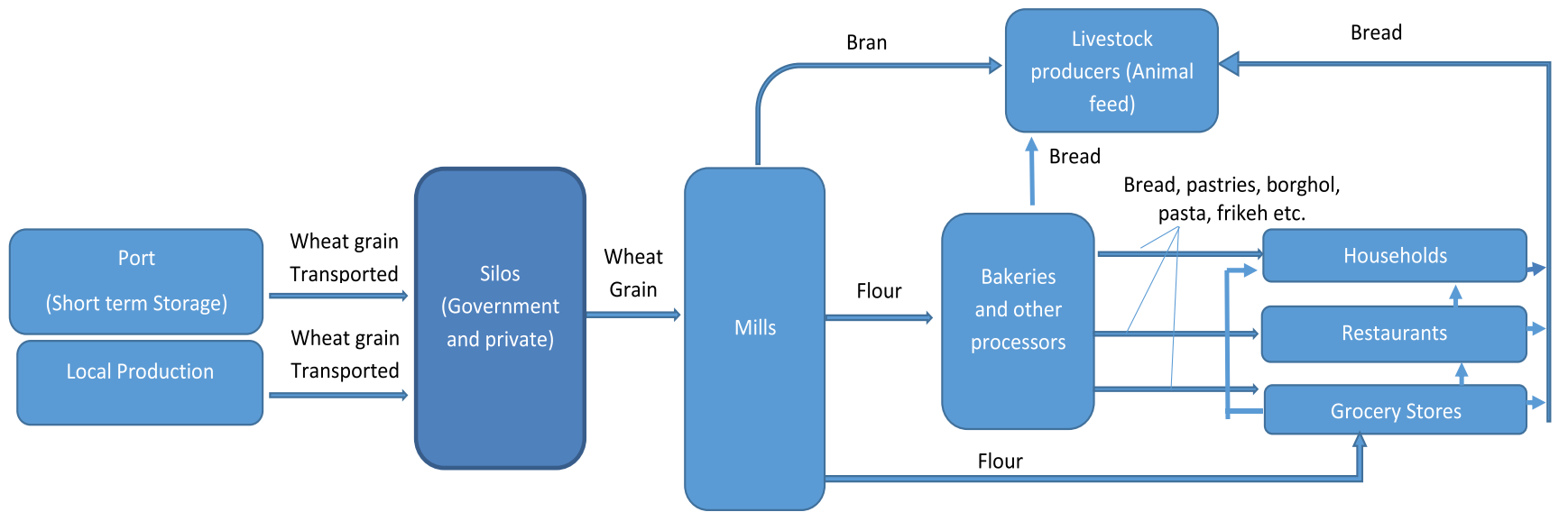

Fig. 1 Description of the wheat value chain in Jordan. Source: depicted by authors 
uses (Hodges et al. 2011). Food losses can be quantitative as measured by decreased weight or volume or can be qualitative such as reduced nutrient value and unwanted changes in taste, color, or cosmetic features of food (Buzby and Hyman 2012).

AOAD (2013) is one of the few papers that provides estimates of losses in the Arab world for different food groups (cereals, legumes, vegetables, etc.) from production to consumption. The document reported that $30 \%$ of total cereal production is lost between production and consumption. While the report provides estimates of loss at the different nodes of the value chains, it does not provide estimates for specific commodities (e.g. wheat, barley, tomatoes, etc.). More importantly, the document does not provide adequate description of how the estimates were generated.

Food losses along the wheat value chain covering harvest and postharvest operations, the latter consisting of transport, storage, processing, to consumption are the focus of this study. To the best knowledge of the authors, studies by Obeidate et al. (2015), Al Rawi (1989) and Snober et al. (1985) are the only ones conducted in Jordan on this subject for field crops. Losses differ across crops and locations. In a study of cereals, Al Rawi (1989) found that $1 \%$ loss occurred due to shattering, bird attack and other factors before harvest while grain losses due to mechanical harvesting were $7.87 \%$. Grain losses due to storage in silos were $0.66 \%$ for wheat (after three months) and $2.37 \%$ for corn (after six months). Our calculations using data from a study of 1644 Jordanian consumers (Obeidate et al. 2015) showed very high levels (28.45\%) of bread waste occurred during consumption.

The objective of this research was to measure the total wheat loss that occurs at each node across the entire wheat value chain in Jordan from the farm (for local production) and port (for imports) to the fork. Losses start to occur in the field before grain is harvested. These losses are hereafter classified into two groups, namely: management losses (the first node) and preharvest losses (the second node). Management losses take the form of yield gaps during crop growth that arise from farmers' deviation from optimal management practices including planting date, seeding rate, the method of planting (broadcasting, row planting or seed drilling), types, amounts and timing of fertilizers, pesticide and herbicide use, and types of varieties used as well as losses occurring due to farmers' skill gaps. The crop losses during the growing period that result from damage by diseases, weeds and insects are also part of management loss. Preharvest losses represent losses incurred after the crop has completed its growth period (i.e., between the period of physiological maturity of the crop and actual harvest date). These losses occur due to natural, varietal and management related causes, including shattering and insect and bird attack. Preharvest losses can be easily prevented if the farmers harvest at physiological maturity.

Losses during storage occur due to a number of factors that characterize the biophysical environment in the storage unit including temperature, humidity, insect or mold activity, birds and rodents, and grain respiration. The effects of each of these possible sources of loss depend on the duration and specific month and season (winter, spring, summer or fall) of the storage period and the genotype.

Transport loss mainly occurs due to spillage during loading, movement and unloading. Marketing loss represents food loss mainly at grocery stores and bakeries and include food thrown into the garbage or fed to animals due to overrun of expiry date or loss of freshness of bread. Consumption loss represents food thrown into the garbage or fed to animals due to overrun of expiry date, loss of freshness in bread, and leftovers. The different nodes of the wheat value chain in Jordan and the types of losses that occur at each are presented in Fig. 2.

\section{Data}

In terms of agricultural production, Jordan can be classified into three broad zones namely: the high potential north, the intermediate potential center and the low potential south. Given very limited financial resources for this study, the sample sizes for the estimation of losses and wastage at the different nodes of the value chain were small and hence we are unable to attach any statistical power. However, despite this limitation, efforts were made to get a good representation of the production and consumption patterns in the country by taking representative samples. There could be possible variation in the type and extent of food waste depending on variation factors. Production-related losses may vary by agroecology and by size of farms as the production methods, varieties and equipment used, amount of labor deployed, weather, and other factors may be different across different agroecologies. There could be differences in the amount of food wasted across household typologies where richer households are expected to waste more as they are likely to buy more but at the same time, the awareness may be higher among some of the richer households and hence may help in reducing waste. There could also be possible differences in efficiency between private and public processing facilities. To avoid possible biases due to such differences, our sample included small-, medium- and large-scale wheat farmers from across all three agro-ecologies (low, medium and high rainfall zones); big and small towns; poor, average and rich households; low-end fastfood restaurants serving mainly the poor, restaurants catering for the middle income portion of the population, and high-end restaurants that target the rich; old, average and new trucks transporting wheat and governmental and private mills.

For pre-harvest and harvest loss measurements, a sample of 30 wheat fields belonging to 30 farmers was selected. The sample was distributed uniformly with 10 fields randomly 
Fig. 2 Wheat losses at different nodes of the wheat value chain. Source: depicted by authors

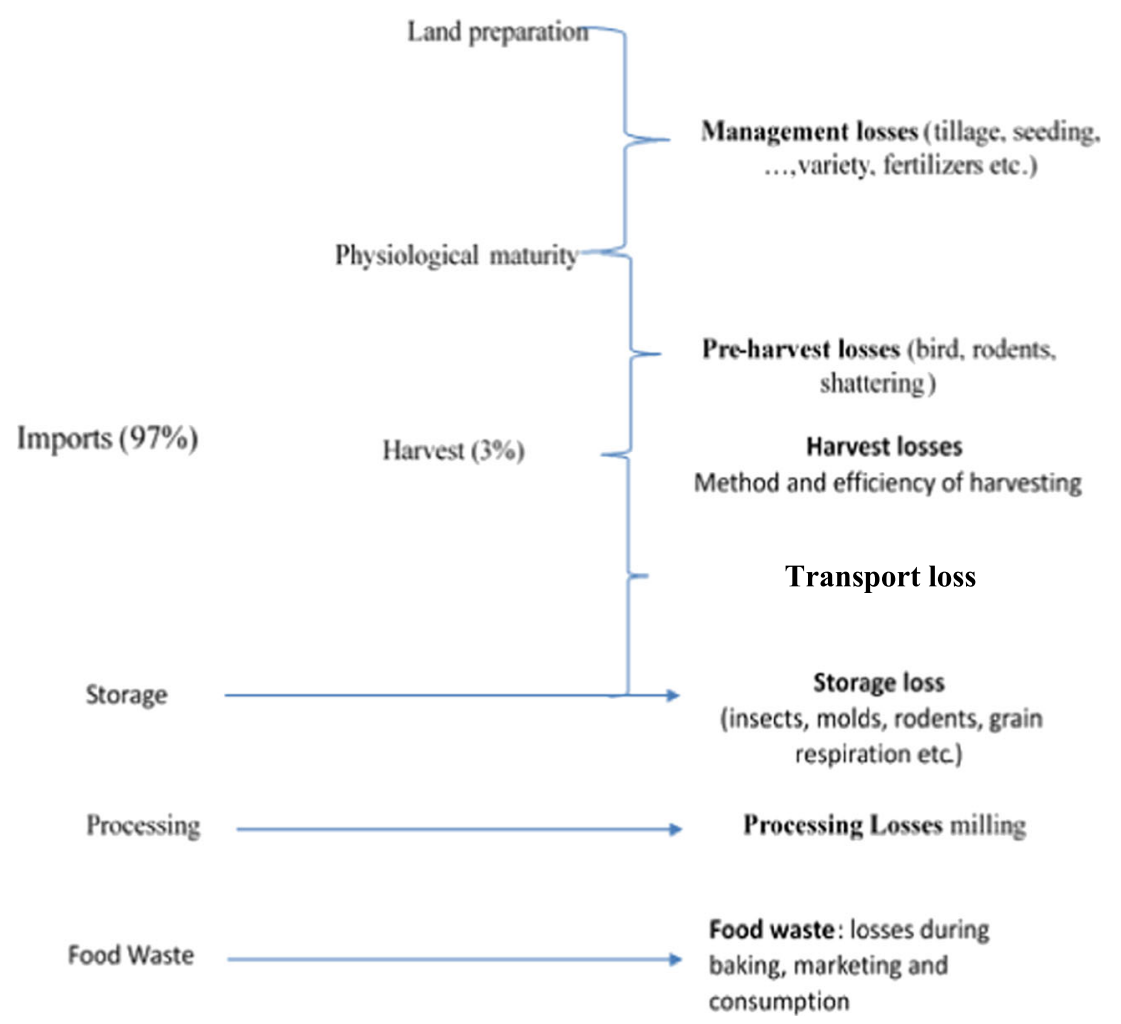

bakeries and patisseries from the three zones (North, Center and South). For measurement of food waste, a sample of 100 households and 100 restaurants (including 2 university cafeterias) were included in the sample. The sample households and restaurants were uniformly distributed among the three zones (North, Center, and South) of Jordan.

\section{Materials and methods}

In this study we followed the life cycle approach suggested by Bellemare et al. (2017), for measuring food loss and waste along the wheat value chain in Jordan - from farm to fork. This approach was used because there is growing concern that estimates of food loss and wastage are exaggerated as food that has been put under alternative uses is also counted as waste while some of it is indirectly consumed by humans. By using the life cycle approach, we were able to make a distinction between food that is no longer available for direct consumption by human beings and that which is consumed indirectly through consumption of meat from animals and/or birds that are fed with leftover bread.

As there are no credible and consistent protocols for food loss and wastage measurement at each node of the wheat value chain, we also developed measurement and estimation protocols which are consistent with the standards for accounting and reporting food loss and wastage developed by an international initiative led by the World Resources Institute (WRI)
Measurement of losses during marketing were determined by taking random samples of 20 grocery stores and six 
(Hanson et al. 2016). For the sake of precision, calculations of losses were made after standardization of all weight measurements throughout the entire value chain into $12 \%$ moisture content. In the interest of space, brief and abridged descriptions of the protocols used for measurement or estimation of losses and/or wastage at the different nodes of the value chain are provided below. The longer and more detailed descriptions of the protocols are available upon request.

\subsection{Protocol used for measuring pre-harvest loss (PrHL)}

For the measurement of pre-harvest loss, the protocol described by Sattar et al. (2015) was used with some modifications. Loss measurements were done at the physiological maturity stage. If the crop growth in the field was visibly homogenous, a random sample of six $1 \mathrm{~m} \times 1 \mathrm{~m}$ quadrats (replicates) distributed across the whole field were taken in such a way that all were at least $5 \mathrm{~m}$ away from the border of the field. However, if the crop growth in the field was visibly heterogeneous, then the field was classified into poor, medium, or good growth and their respective share (\%) in the total area of the field estimated. Then, a random sample of 2 quadrats from each category (making a total sample of six quadrats from the entire field) was taken making sure that each quadrat was $5 \mathrm{~m}$ away from the border. Regardless of the homogeneity/heterogeneity of the field, we made sure that the distance between each replicate was at least $20 \mathrm{~m}$.

\subsection{Protocol used for harvest loss (HL) measurement}

Losses that occurred at the harvest stage are due to the method of harvesting (manual or combine harvester) and due to poor calibration of the combine harvesters. For measuring harvest losses, three options were compared: A) Manual harvesting and hand threshing; B) Mechanical harvesting using farmers' combines with their own calibration; and C) Mechanical harvesting using farmers' combines but calibrated by an expert from the research team. Most Jordanian farmers have moved away from manual harvesting into mechanical harvesting. If carefully done, manual harvesting gives maximum yield and minimum harvesting loss (Clay et al. 2012). Therefore, the loss obtained from this measurement (item A above) was used as the benchmark against which all other harvesting and threshing options considered in this study were compared. The differences between items $\mathrm{A}$ and $\mathrm{B}$ and $\mathrm{A}$ and $\mathrm{C}$ give estimates of the harvest-related losses endured by farmers.

\subsection{The protocol used for measuring management-related losses in the field}

Measuring management related losses during crop growth is not straight forward as it represents the yield gap not only arising from the use of obsolete varieties but also the use of suboptimal agronomic practices and inherent inefficiencies of the farmer. This is even more difficult when the intention is to make physical measurements. As a result, crop simulation models are often used to make estimations about yield gaps which essentially represent management/agronomic losses (Lobell 2013). Since no adequate data are available for calibrating a suitable crop simulation model for this task, the Stochastic Frontier Production Function (SFPF) approach (Battesse and Coelli 1995) was used to indirectly measure management related losses. Suppose that the estimate of the average productive efficiency from the econometric estimation of a stochastic frontier production function (SFPF) is given by A (in \%). Then, total loss on the field (TFL) is calculated as $100 \%$-A. We then indirectly calculated the total management loss on the field (ML) as: ML $=$ TFL - PrHL HL where PrHL is pre-harvest loss and HL is harvest loss (both of which are measured using protocols described in Sections 4.1 and 4.2).

\subsection{Protocol used for measuring storage losses}

Storage losses are best estimated using models such as the PHAST-FEM (Montross et al. 2002), as they use biophysical relationships based on historical ambient and in-bin temperature, relative humidity $(\mathrm{RH})$, pest activity and grain biology. Due to the lack of in-bin temperature and $\mathrm{RH}$ measurements in the Jordanian silos, an attempt was made to carry out physical measurements for storage losses using rudimentary methods. Furthermore, due to the limited access to silos, storage lossrelated measurements were taken only for four monthly data points covering the period July-October in three out of the four silos while an additional measurement for November was made in one silo. Grain sampled from the silos and kept in hermetic bags were used as the reference weight against which grain samples taken directly from the silos every month were compared. The average difference in the weights between the grain in the hermetic bag and those sampled from the silos each month were considered to provide an estimate of storage loss. As measurements were taken only for four months, some ad-hoc assumptions were made for the estimation of losses during the months for which measurements were not taken.

\subsection{Protocol for measuring transport losses}

Physical measurements were used to compute transport losses. Transport losses were computed as the difference in the weight of trucks loaded with wheat grain before departure from the silos in the port of Aqaba and after arrival of the same shipment at one of the long-term storage silos inland. As local production represented only $3 \%$ of total national wheat supply, the same level of loss as that measured for imported wheat is assumed for local production as well. 


\subsection{Protocol for measuring processing losses}

According to the standard protocol (FMA 2016), four different types of measurements can be used to measure milling loss during a fairly long period of time such as monthly losses. While these calculations provide good insights in terms of what is actually happening, tracking each of the variables for a long period especially in mills where there are huge movements in and out of the mill with large carryovers to the next period (e.g. end of the month) could be particularly difficult. In such situations, another protocol, which we call daily loss, proved to be much easier and hence was used in this study. Daily loss was calculated as the difference between the total weight of wheat grain that is milled in one day and the total weight of the flour produced during that day (both converted to $12 \%$ moisture content equivalents).

\subsection{Protocol for measuring food waste}

Food wastage can be caused by various factors and can take different forms including: 1) loss in quantity of food prepared for consumption, especially when leftover food (left on the plate or even not served) is thrown away; 2) food wasted when it is thrown away after it is prepared due to its deterioration in quality and edibility, making it unfit for human consumption; 3) processed, semi-processed and raw food items thrown away (by households, grocery stores, bakeries, etc.) because they have reached the end of their shelf life (or expiration date).

Food waste at households, restaurants, grocery stores, and bakeries was based on survey data where we calculated the amount of loss as the difference between the amount of flour/bread coming in (purchased) and the amount that was sold/consumed. During the survey, the appropriate individual responsible for preparing food in the household (often a woman), the restaurant or university was interviewed to give estimates of the percentage of food thrown away: a) before food is prepared because of expiration of usage date, $b$ ) after it was prepared but before it was served because it was prepared excessively or because it did not come out well (or because it was spoiled due to the elapse of too long a period after preparation) and c) after it was prepared/ordered because it was excessive. For comparison purposes, physical measurement of food waste after consumption at restaurants was carried out (please note that the food waste after consumption is only one aspect as there is also wastage of bread which has not been served which represents order/preparation in excess of demand which we estimated using survey data).
The following formula was used to compute food wastage during or after consumption:

Total amount of food waste $=\sum_{i}$ Waste factor $_{i} *$ Scaling factor ${ }_{i}$

Where:

$i=$ category of: households (poor, medium and rich), restaurants (high-end, middle-class and low-end restaurants), grocery stores and bakeries (small, medium and large stores/ bakeries);

Waste factor $r_{i}$ represents the average amount of wasted bread by a single household/restaurant, grocery store/ bakery in category $i$ in a given period of time;

The scaling factor $r_{i}$ is the total number of households, restaurants, grocery stores, bakeries in category $i$ throughout Jordan.

\section{Results and discussion}

\subsection{Pre-harvest loss}

The average farm size in Jordan is 6 ha. The area-weighted national average pre-harvest losses was about $12.3 \mathrm{~kg} / \mathrm{ha}$ with the highest loss $(14.9 \mathrm{~kg} / \mathrm{ha})$ registered for the producers in the southern regions of Jordan. Therefore, every farm is losing (at pre-harvest) an average of $73.8 \mathrm{Kg}$ of wheat. Using the minimum wheat grain price of $370 \mathrm{JD} /$ tonne, the total value of wheat that could be saved per farm was $27.31 \mathrm{JD}$ and using area weights for upward aggregation of regional estimates into national figures, the total loss in the country was estimated at $287.01 \mathrm{ton} /$ year and 106,193.7 JD (Table 2).

\subsection{Harvest loss}

Averages yields using manual harvesting in $(\mathrm{kg} / \mathrm{ha})$ for north, central and south regions were 3832,3860 , and 2586 respectively (Table 3 ). The national average yield (using area weights for upward aggregation) was $3437 \mathrm{~kg} / \mathrm{ha}$. Yields from mechanical harvesting using farmers' own calibration for north, central and south were 3578,3369 and $2385 \mathrm{~kg} / \mathrm{ha}$ respectively. The national weighted average yield was $3169 \mathrm{~kg} / \mathrm{ha}$. The corresponding figures for mechanical harvest using expert calibration for the north, central and south were 3674,3611 and $2662 \mathrm{~kg} /$ ha respectively. The area-weighted average yield was $3342 \mathrm{~kg} / \mathrm{ha}$.

Using the yield from manual harvesting as the reference yield, the average yield losses due to mechanical harvesting using farmer calibration and expert calibration and the small research combiner were $267.9 \mathrm{~kg} / \mathrm{ha}, 95.1 \mathrm{~kg} / \mathrm{ha}$ and $78.5 \mathrm{~kg} /$ ha which represented a total national loss of 6167.25 tons/year, 2188.36 tons/year and 1805.94 tons/year, respectively. 
Table 2 Estimation of preharvest loss at the national level per year

\begin{tabular}{lllll}
\hline Location/variable & $\begin{array}{l}\text { Total wheat } \\
\text { Area (ha) }\end{array}$ & $\begin{array}{l}\text { Pre-harvest loss } \\
(\mathrm{kg} / \mathrm{ha})\end{array}$ & $\begin{array}{l}\text { Total loss in the } \\
\text { country (tons/year) }\end{array}$ & $\begin{array}{l}\text { Minimum value } \\
\text { of grain loss }\end{array}$ \\
\hline North & $12,660.07$ & 11.03 & & \\
Central & 2992.38 & 12.61 & \\
South & 7365.86 & 14.88 & & \\
National average (area-weighted) & & 12.47 & 287.01 & $104,465.12$ \\
Total & $23,018.30$ & & \\
\hline
\end{tabular}

Source: Authors' calculation
By improving the calibration of their combines alone, farmers could reduce loss of $172.9 \mathrm{~kg} / \mathrm{ha}$ or nationally 3978.89 tons/year. This loss, which can easily be avoided by hiring an expert to calibrate farmers combine harvesters, was estimated at
64JD/ha. Currently, there is no market for combine harvester calibration in Jordan. However, farmers could make additional profit of at least $34 \mathrm{JD} /$ ha if they were to pay even as much as 30JD/ha to hire an expert to calibrate a combine harvester.

Table 3 Estimation of yield for manual, mechanical harvest with and without calibration and harvesting by using small combines in Jordan

\begin{tabular}{|c|c|c|c|c|}
\hline Location & $\begin{array}{l}\text { Manual-Average } \\
\text { production } \\
(\mathrm{kg} / \mathrm{ha})\end{array}$ & $\begin{array}{l}\text { Mechanical-expert-calibration-Average } \\
\text { production }(\mathrm{kg} / \mathrm{ha})\end{array}$ & $\begin{array}{l}\text { Mechanical-farmer-calibration-Average } \\
\text { production }(\mathrm{kg} / \mathrm{ha})\end{array}$ & $\begin{array}{l}\text { Mechanical-small } \\
\text { research } \\
\text { Combine-Average } \\
\text { production }(\mathrm{kg} / \mathrm{ha})\end{array}$ \\
\hline North & 3832.0 & 3673.9 & 3578.0 & 3692.2 \\
\hline Central & 3860.0 & 3610.6 & 3368.6 & 3628.6 \\
\hline South & 2586.4 & 2662.4 & 2385.4 & 2675.6 \\
\hline $\begin{array}{l}\text { National average } \\
\text { (simple) }\end{array}$ & 3426.1 & 3315.6 & 3110.6 & 3332.1 \\
\hline $\begin{array}{l}\text { National average } \\
\quad \text { (weighted) }\end{array}$ & 3437.0 & 3342.0 & 3169.1 & 3358.6 \\
\hline $\begin{array}{l}\text { Loss relative to manual } \\
\text { harvesting }(\mathrm{Kg} / \mathrm{ha})\end{array}$ & 0.00 & 95.1 & 267.9 & 78.5 \\
\hline \multirow{2}{*}{\multicolumn{5}{|c|}{$\begin{array}{l}\text { Loss relative to } \\
\text { calibrated combines } \\
\text { Estimation of Average } \\
\text { National loss }\end{array}$}} \\
\hline & & & & \\
\hline & Loss (kg/ha) & $\begin{array}{l}\text { Total loss in the country } \\
\text { (tons/year) }\end{array}$ & \multicolumn{2}{|l|}{$\begin{array}{l}\text { Minimum value of grain that } \\
\text { can be saved }\end{array}$} \\
\hline $\begin{array}{l}\text { Total loss due to } \\
\text { mechanical } \\
\text { harvesting (farmer } \\
\text { calibration) }\end{array}$ & 267.93 & 6167.25 & \multicolumn{2}{|l|}{$2,281,882.72$} \\
\hline $\begin{array}{l}\text { Total loss due to } \\
\text { mechanical } \\
\text { harvesting (expert } \\
\text { calibration) }\end{array}$ & 95.07 & 2188.36 & \multicolumn{2}{|l|}{$809,691.88$} \\
\hline $\begin{array}{l}\text { Total loss due to } \\
\text { mechanical } \\
\text { harvesting (small } \\
\text { research } \\
\text { combine-harvester) }\end{array}$ & 78.46 & 1805.94 & \multicolumn{2}{|l|}{$668,198.58$} \\
\hline $\begin{array}{l}\text { Loss from mechanical } \\
\text { harvest (due to } \\
\text { difference in } \\
\text { calibration) }\end{array}$ & 172.86 & 3978.89 & \multicolumn{2}{|l|}{$1,472,190.84$} \\
\hline $\begin{array}{l}\text { Loss that can easily be } \\
\text { avoided by hiring an } \\
\text { expert to calibrate } \\
\text { farmers' combine } \\
\text { harvesters }\end{array}$ & 172.86 & 3978.89 & \multicolumn{2}{|l|}{$1,472,190.84$} \\
\hline
\end{tabular}

Source: Authors' own calculations 


\subsection{Management losses}

The observed (actual) average yield (YO), for the randomly selected samples from the three regions (north, central and south) was $2364.7 \mathrm{~kg} / \mathrm{ha}$ (Table 4). The efficiency level of the typical farmer was estimated at $80.3 \%$, which shows that on the average farmers are losing $579 \mathrm{~kg} / \mathrm{ha}$ out of a total potential production at physiological maturity of $2644.9 \mathrm{~kg} /$ ha. This shows that the total potential yield in the absence of all preharvest, harvest and postharvest losses was $2943.8 \mathrm{~kg} /$ ha. Given that the total loss between physiological maturity and harvest was measured to be $280.2 \mathrm{~kg} / \mathrm{ha}$, the total management-related loss is $298.8 \mathrm{~kg} / \mathrm{ha}(2943.8-280.2)$. This translates into a total national loss of 6878.71 tons/year $(0.76 \%)$.

\subsection{Transport losses}

The total transport loss was estimated at $0.29 \%$ which translated to 2553.38 tons/year. It is important to note here that the quantity lost during transport depended on the kinds of trucks (old vs. new and dumpster vs. semi-trailer trucks) where old dumpster trucks with holes were found to be the ones with the highest loss. Were Jordan to upgrade all the old trucks transporting wheat, it would have prevented the loss of 508 tons of wheat every year.

\subsection{Storage losses}

After converting all weight measurements into their $12 \%$ moisture content equivalents, the loss during the period
July-November for which actual measurements were taken was $6.65 \%(33,269$ ton/year) with the highest loss $13,702.24$ tons $(2.74 \%)$ occurring in the month of August followed by $10,893.14$ tons $(2.18 \%)$ in September (Tables 5). As measurements for the months between December and June were not taken, ad-hoc assumptions were made to generate estimates of loss during this period. For example, because the temperature in Jordan drops between October and March to levels which are prohibitive of insect and mold growth, we assumed a very low storage loss of $0.05 \%$ per month for this season. Whereas, as temperature starts to rise starting from April, higher and exponentially increasing monthly loss rates are expected until August after which temperature starts to fall leading to lower losses as well. Based on experience, the storage loss in June is assumed to be comparable to the measured loss in September $(0.29 \%)$ while that of May is assumed to be $40 \%$ less than that of June and the loss in April is also assumed to be $40 \%$ less than that in May. Based on these ad-hoc assumptions, the total storage loss per year was estimated at $11.10 \%$ or $55,546.33$ tons/year. However, the research team does not have full confidence on the validity of this figure as there are no past data or studies that can be used to substantiate the validity of the assumptions that were made. Therefore, the storage loss of $6.65 \%$ that is measured for the period July-November is reported as the minimum estimate of the annual storage loss in Jordan.

\subsection{Processing losses}

Data obtained from the sample private mill was not reliable. Therefore, the results were not included in the analysis and the
Table 4 Estimation of management losses for wheat in Jordan

\begin{tabular}{ll}
\hline Mean yield (ton/ha) & 2.34 \\
Observed or actual average Yield (YO)= & 236.47 \\
Pre-harvest loss (PRHL) in kg/ha= & 12.3 \\
Harvest-loss (HL) in kg/ha= & 267.9 \\
Total pre-harvest and harvest loss (kg/ha) & 280.2 \\
Potential yield at maturity date (kg/ha) & 2644.9 \\
Total pre-harvest and harvest loss as \% of total potential production of wheat in Jordan $(\%)=$ & $9.52 \%$ \\
Average efficiency level from SFPR (\%) = & $80.3 \%$ \\
Potential Yield in the absence of all losses (YP) (kg/ha) = & 2943.8 \\
Total production loss (as \% of potential yield) = & $19.7 \%$ \\
Agronomic loss (kg/ha) = & 298.8 \\
Total agronomic loss as \% of total potential production of wheat in Jordan (\%) & $10.15 \%$ \\
Total wheat area in Jordan in ha= & 23,018 \\
Total agronomic loss in Jordan (tons per year) = & 6878.71 \\
Average annual imports of wheat in Jordan (tons/year) & 851,115 \\
Total amount of wheat that is actually available in Jordan (tons/year) & $904,980.56$ \\
Total amount of wheat that should have been available in Jordan (tons/year) & $918,170.34$ \\
Total agronomic loss as \% of total actual production and imports in Jordan $(\%)$ & $0.76 \%$ \\
\hline
\end{tabular}

Source: Authors' own calculation 


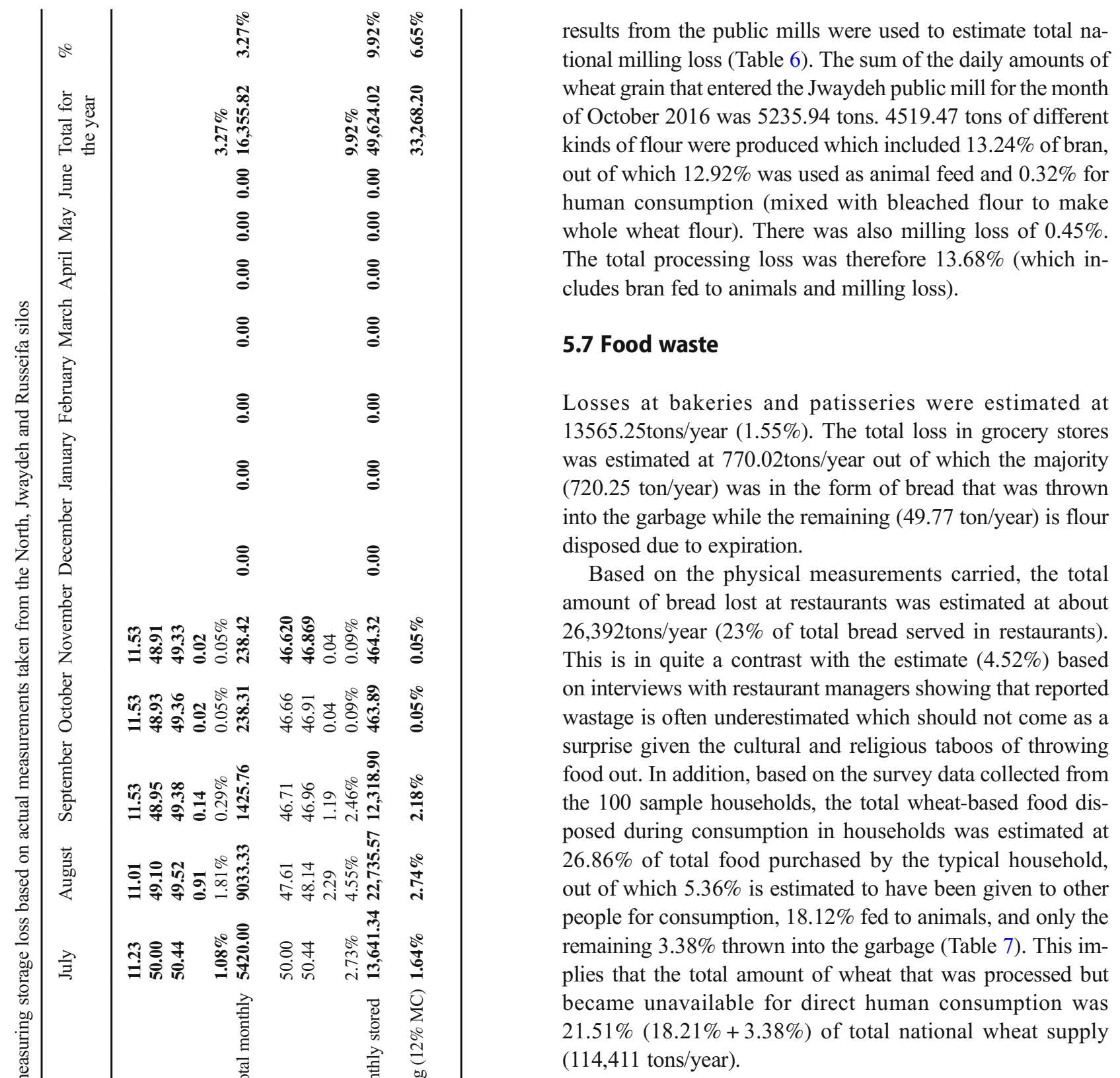

\subsection{Discussion}

Table 8 provides the detailed accounting of losses from the field (for local production) and the port (for imports) all the way to the fork. Grain was tracked along each node in the entire value chain where cumulative losses that were incurred in preceding nodes were deducted from the total amount entering the subsequent nodes. To make the estimation consistent, all wheat and wheat products at each node were converted into uniform moisture content of $12 \%$. Accordingly, total management (agronomic) losses were estimated at $10.15 \%$ of potential production while pre-harvest and harvest losses were $0.42 \%$ and $9.10 \%$ respectively. However, given that local production is only $3 \%$ of total food supply in the country, the total loss in the field (including all agronomic, pre-harvest 
Table 6 Summary of milling loss based on 30-days data from Jwaydeh Mills

\begin{tabular}{|c|c|c|c|c|c|c|}
\hline & Bran for animals & Bran for humans & & & & \\
\hline Suppose that: & & & Tons per month & Total \% & Animals & Humans \\
\hline $\mathrm{a}=$ Raw $/$ dirty wheat used in first break & & & 5236.0 & & & \\
\hline $\mathrm{b}=$ flour produced & & & 4519.5 & & & \\
\hline $\mathrm{c}=$ screenings $/$ dockage & & & 0 & & & \\
\hline $\mathrm{d}=$ mill-feed/offal (waste material) & & & 0 & & & \\
\hline $\mathrm{e}=$ bran & 676.42 & 16.7 & 693.1 & $13.24 \%$ & $12.92 \%$ & $0.32 \%$ \\
\hline \multicolumn{7}{|l|}{ Calculation methods } \\
\hline 1. Raw/dirty wheat & & & & $13.68 \%$ & & \\
\hline 2. First break & & & & $13.68 \%$ & & \\
\hline 3. Total products & & & & $13.30 \%$ & & \\
\hline \multirow{2}{*}{$\begin{array}{l}\text { 4. Mill gain }(-) \text { or loss }(+) \text { excluding bran } \\
\text { for animal and human consumption }\end{array}$} & & & In tones & 23.34 & & \\
\hline & & & In $\%$ & $0.45 \%$ & & \\
\hline
\end{tabular}

Source: Author's own calculation

and harvest losses) was estimated at only $1.47 \%$ of total food supply in the country. Measurement for transport loss was carried out only for wheat grain transported from the port to the different silos. It is assumed that it will be the same also for loss during transport from the field (for local production) to the silos. Loss during transport from ports and fields to the silos was only $0.29 \%$.

The total annual storage loss was estimated at $11.1 \%$. However, as no physical measurement was taken for the period December - June, we had to make ad-hoc assumptions

Table 7 Food waste during consumption by households

\begin{tabular}{|c|c|c|c|c|c|c|c|c|c|c|}
\hline \multirow[t]{2}{*}{ Item } & \multicolumn{3}{|c|}{$\begin{array}{l}\text { Food wasted after serving } \\
\text { (kg/day) } \\
\text { (at } 12 \% \mathrm{MC} \text { Wheat } \\
\text { Equivalents) }\end{array}$} & \multicolumn{3}{|c|}{$\begin{array}{l}\text { Food wasted untouched } \\
\text { (kg/day) } \\
\text { (at } 12 \% \mathrm{MC} \\
\text { Wheat Equivalents) }\end{array}$} & \multicolumn{4}{|c|}{$\begin{array}{l}\text { Total wastage in the total Jordanian households } \\
\text { (at } 12 \% \mathrm{MC} \text { Wheat Equivalents) }\end{array}$} \\
\hline & Garbage & Human & Animal & Garbage & Human & Animal & Garbage & Human & Animal & Grand total \\
\hline White bread (khubz) & 0.00342 & 0.01499 & 0.00085 & 0.00062 & 0.00124 & 0.00808 & 7986.33 & $32,098.91$ & $17,662.08$ & $57,747.33$ \\
\hline Medium white wheat bread (khubz) & 0.00039 & 0.01165 & 0.00124 & 0.00093 & 0.00000 & 0.00031 & 2610.92 & $23,037.50$ & 3071.67 & $28,720.08$ \\
\hline Black (whole) wheat bread (khubz) & 0.00404 & 0.00039 & 0.00450 & 0.00000 & 0.00062 & 0.00132 & 7986.33 & 1996.58 & $11,518.75$ & $21,501.66$ \\
\hline $\begin{array}{l}\text { Other white bread (baguette, slices, } \\
\text { buns, rolls, etc.) }\end{array}$ & 0.00000 & 0.00000 & 0.00047 & 0.00000 & 0.00777 & 0.01553 & - & $15,358.33$ & $31,638.16$ & $46,996.49$ \\
\hline $\begin{array}{l}\text { Other whole wheat bread (baguette, } \\
\text { slices, buns, rolls, etc.) }\end{array}$ & 0.00000 & 0.00155 & 0.00000 & 0.00000 & 0.00000 & 0.00000 & - & 3071.67 & - & 3071.67 \\
\hline $\begin{array}{l}\text { Pasta (macaroni, spaghetti, tagliatelle, } \\
\text { lasagna, etc.) }\end{array}$ & 0.00440 & 0.00000 & 0.00070 & 0.00704 & 0.00000 & 0.00440 & $22,611.30$ & - & $10,088.12$ & $32,699.42$ \\
\hline Bourghul & 0.00020 & 0.00049 & 0.00489 & 0.00000 & 0.00000 & 0.00000 & 386.52 & 966.30 & 9662.95 & $11,015.76$ \\
\hline Friekhe & 0.00000 & 0.00000 & 0.00000 & 0.00000 & 0.00000 & 0.00000 & - & - & - & - \\
\hline Cakes & 0.00000 & 0.00000 & 0.00000 & 0.00000 & 0.00000 & 0.00000 & - & - & - & - \\
\hline Cookies and biscuits & 0.00000 & 0.00000 & 0.06157 & 0.00000 & 0.00000 & 0.00000 & - & - & $121,753.17$ & $121,753.17$ \\
\hline Manaeish & 0.00000 & 0.00000 & 0.00000 & 0.00000 & 0.00000 & 0.00000 & - & - & - & - \\
\hline \multirow[t]{2}{*}{ Flour } & 0.00391 & 0.00078 & 0.02003 & 0.00000 & 0.00000 & 0.00968 & 7730.36 & 1546.07 & $58,750.74$ & $68,027.17$ \\
\hline & 0.01635 & 0.02985 & 0.09426 & 0.00859 & 0.00963 & 0.03931 & $49,311.76$ & $78,075.36$ & $264,145.64$ & $391,532.76$ \\
\hline \multicolumn{10}{|c|}{ Total amount of wheat-based products purchased by the households (tons/year) } & $531,999.06$ \\
\hline \multicolumn{7}{|l|}{ Total number of households in Jordan } & & & & $1,977,534.00$ \\
\hline \multicolumn{7}{|c|}{ Total national amount of food wasted at household level (tons/day) } & 49.31 & 78.0 & 264.15 & 391.53 \\
\hline \multicolumn{7}{|c|}{ Total national amount of food wasted at household level (tons/year) } & $17,998.79$ & $28,497.51$ & $96,413.16$ & $142,909.46$ \\
\hline \multicolumn{7}{|l|}{ Total loss $(\%)$} & $3.38 \%$ & $5.36 \%$ & $18.12 \%$ & $26.86 \%$ \\
\hline
\end{tabular}

Source: Authors' own calculation 


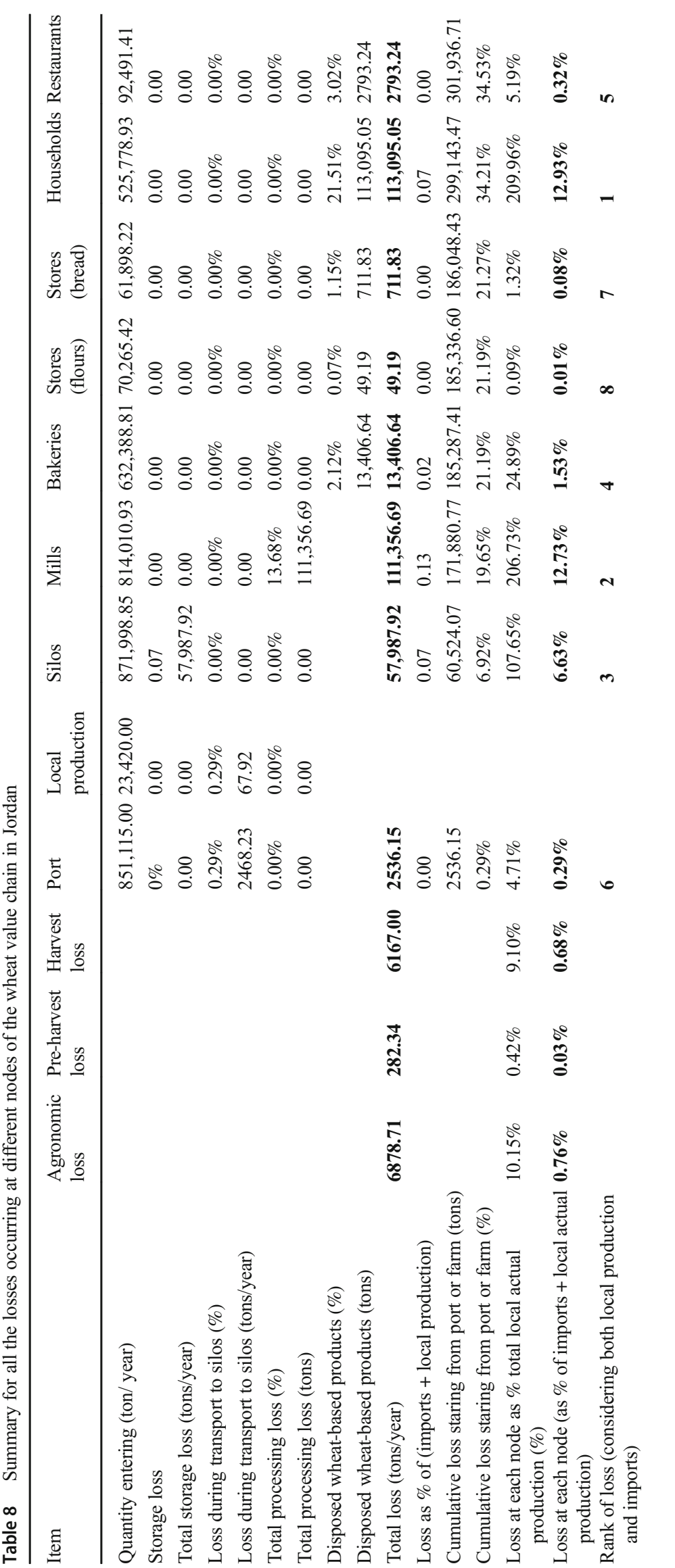


with which we are not comfortable. Therefore, we consider here only the storage loss for the period July-November for which physical measurement was taken. During this period alone, storage loss in the country was estimated at $6.65 \%$. Likewise, the total processing loss (loss at flour mills) was estimated at $12.75 \%$ of total wheat supply in the country. Over $97 \%$ of the total loss at the flour mills represents bran that is sold to farmers as animal feed. The loss at bakeries, grocery stores and restaurants were, respectively, $1.55 \%$, $0.09 \%$ and $0.32 \%$. With a total loss of $12.95 \%$, food loss and wastage at household level ranks first followed by that which is lost during milling $(12.73 \%)$. However, given that almost all the loss at the mills is given to animals, one can argue that it is not lost.

In summary, the total amount of lost wheat is estimated at 301.9 thousand tonnes $(34.53 \%)$ which, using a five-year average price of US $\$ 350 /$ ton, is equivalent to US $\$ 105.3$ million per year. Food lost or wasted also means energy and water lost/wasted (Verma 2015; Cuéllar and Webber 2010). The average amount of water needed to produce one kilogram of wheat is $1.1 \mathrm{M}^{3}$ (Yigezu et al. 2014 for Syria; Hussain et al., 2003 for Pakistan). The average amount of water needed to process $1 \mathrm{~kg}$ of wheat equivalent flour into bread is $0.781 / \mathrm{kg}$ (Food, 2009). Likewise, the average energy needed for producing 1 ton of wheat was about $3223 \mathrm{MJ}$ (Fox and Fimeche 2013) and for baking is about $5338 \mathrm{MJ}$ per ton (Beech and Crafts -Lighty 1980). Using the above parameters from previous studies, the total amount of water lost due to total food loss and wastage (including the food given to animals) in Jordan is estimated at 348 million $\mathrm{m}^{3}$ (99\% for production and only $1 \%$ for processing) valued at $\$ 41$ million. The wheat loss in Jordan also implied a total loss of 3.68 million GJ of energy ( $27.64 \%$ for production and $73.36 \%$ for processing) which is equivalent to 115 million liters of diesel with an estimated value of $\$ 70$ million.

Households, restaurants, bakeries and grocery stores were asked what they do with unconsumed or unsold bread and wheat-based products (particularly flour). Almost all of them said they give it to animals. However, due to religious and cultural values in the region, the estimates of bread used as animal feed are likely over estimated. Stacks of bread thrown inside or beside garbage dumpsters are a common scene in major cities in Jordan. Interviews with 10 municipality workers who are responsible for lifting garbage dumpsters revealed that bread constitutes between $10 \%$ and $30 \%$ of the total amount of garbage collected. Therefore, the estimates of bread used as animal feed is likely to be overestimated while that which is thrown into the garbage is under estimated. But even if the respondents' figures were accurate, the total amount of food that is thrown away into the garbage was 84,385 tons/year $(9.65 \%)$. Moreover, feeding animals with bread, the production of which requires substantial amounts of energy, water and labor, is a waste of natural and financial resources. Using the import prices of wheat ( $\$ 350 /$ ton) and barley ( $\$ 250 /$ ton) and the estimated cost of producing and processing $1 \mathrm{~kg}$ of wheat into bread, Jordan is losing $43 \%$ and $48 \%$ respectively of total protein and energy for every 1US\$ spent on bread that is fed to animals instead of equivalent value of barley. Alternatively, if Jordan were to feed the animals with raw wheat instead of bread, the country would have saved $31 \%$ of both energy and protein for every dollar spent on bread fed to animals.

\section{Conclusions and recommendations}

Being a major global issue, food waste and loss remain relatively unexplored topics especially in the Middle East in general and in Jordan in particular. While there are rough estimates of the total global food losses, most of them are either based on expert opinions and hence vary widely or they do not provide clear explanation on what was being estimated, how the estimation was made, and when. More importantly, only few of them provide detailed breakdown in terms of where in the value chains exactly these losses are taking place. Food losses and waste can happen at different nodes of the value chain, namely: in the field during the growing periods of the crop, at harvest, at storage and during transport, processing, marketing, and consumption. Having estimates of losses at each of these nodes will be highly valuable for policy making and targeting and prioritizing interventions.

In this paper, we attempted to estimate the total wheat loss that occurs at each node across the entire wheat value chain in Jordan from the farm (for local production) and port (for imports) to the fork. Except for the pre-harvest, transport and marketing nodes, substantial losses are recorded at each of the other nodes along the wheat value chain. Using a combination of physical measurements and surveys, we estimated that at least $34 \%$ of total wheat supply in Jordan (both from local production and imports) is lost or wasted - costing the country about US\$105 million per year directly.

This research adds value to the global community in general and Jordan in particular in many different ways. 1) It contributes to the literature both in terms of providing a complete set of protocols for food loss and wastage measurement along the wheat value chain (from farm to fork); 2) it also contributes to the literature by providing estimates of food losses and waste at each node of the value chain using a combination of physical measurements and scientifically defendable estimation procedures which are then aggregated into national levels - an attempt, which to the best of our knowledge, has not been made by any other study. 3 ) In the course of this study, important discussions have already started to emerge, and the findings have provided useful information which we believe has contributed to the recent changes introduced by the Jordanian government. It is also expected to 
continue benefiting the country and other countries in the region with similar production, socio-cultural and political environments.

Postharvest losses were found to be important in Jordan. Particularly, the major losses that occur at the household level where processed food (mostly bread) is either thrown away into the garbage or given away for use as animal feed. Food loss and wastage at household level represent about $12.95 \%$ of the total wheat available in the country. The total amounts of water and energy that were expended to produce wheat lost or wasted in Jordan are respectively estimated at 348 million $\mathrm{m}^{3}$ and 3.68 million GJ (which is equivalent to 115 million liters of diesel) valued at about $\$ 41$ million and $\$ 70$ million respectively.

During personal interviews with heads of the 100 sample households and managers of the sample restaurants, bakeries and grocery stores, it was emphasized that most (84\%) of the unconsumed bread was given to farmers for use as animal feed. However, due to religious and cultural taboos in the region, the estimates of bread thrown away are believed to have been underestimated. Some justifications in favor of our argument include stacks of bread thrown inside or beside garbage dumpsters are a common scene in major cities of Jordan. However, even if the respondents were accurately reporting, feeding animals with bread which has been produced using substantial amounts of energy, water and labor is a waste of natural and financial resources. Using standard conversion factors, we estimated that Jordan is losing $43 \%$ and $48 \%$ respectively of total protein and energy for every 1US\$ spent on bread that is fed to animals instead of the equivalent amount of barley. Alternatively, if Jordan were to feed the animals with raw wheat instead of bread, the country would have saved $31 \%$ of both energy and protein for every dollar spent on bread fed to animals.

The findings of this study show that postharvest losses, particularly processed food wastes that are used as animal feed in Jordan are very high. Disregarding the nutritional advantages of feeding raw wheat, given the high cost of energy, labor, water and other resources for processing, using bread as animal feed is not an optimal option for Jordan. These phenomena signal an urgent need for individuals, civic society organizations, NGOs and the government to make concerted efforts towards awareness raising and measures targeting reduction in losses, particularly food waste at household levels that end up as animal feed.

Jordan cannot afford to and should not continue with such a great magnitude of loss. Given the high levels of water and energy constraints in the country and the very high opportunity cost of the financial resources devoted to the production and import of wheat in the country, investment towards reducing food loss and wastage is imperative. While finding solutions to the various kinds of losses will require more research, some minor behavioral, cultural and institutional changes as well as policy changes at individual, society and national levels could go a long way in reducing these losses. Among other matters, the following changes could help to reduce food loss and wastage in Jordan:

1. Awareness should be created among society about the magnitude of wheat loss and wastage and its moral implications and resource use inefficiency.

2. Options for smaller package sizes or bundles of $0.1 \mathrm{~kg}$, $0.25 \mathrm{~kg}, 0.5 \mathrm{~kg}$ and $1 \mathrm{~kg}$ and even piece-meal sales of bread should be provided by bakeries. These will enable smaller and prudent families to buy only the quantity of bread that they consume.

3. Jordan should study carefully the option of replacing flour subsidies with bread subsidies. Furthermore, introducing a voucher system which enables the subsidy in the country to target only poorer families and motivate them to be careful in their use of bread would be more effective in both reducing bread waste and also improving nutritional diversity of the poor. Studying better approaches (including the recent approach adopted by the Egyptian government) of providing vouchers to the needy while bread is sold at its actual production cost might be beneficial.

4. Increased investment in research to reduce losses at each node of wheat value chain, particularly losses occurring during consumption at the household level.

5. Installation of equipment for the measurements of temperature and relative humidity in all Jordanian silos to help monitor the grain in the silos as well as for generating better and more reliable estimates of storage losses.

Over the course of the production of the dissertation which led to this paper, there have been many discussions on the topic of food loss and wastage in Jordan (see for example Duwayri 2016). In January 2018, the Jordanian government reduced the amount of subsidy. Instead, poor households were given a certain amount of cash every year as compensation for the higher bread prices. While this is a move in the right direction, whether it is effective in addressing the problem and if its implementation can be improved needs to be studied.

One of the major limitations in this study is that due to limited funding, the sample sizes were small. Larger sample sizes would provide statistical confidence and this will be a matter for future endeavors.

Acknowledgements Financial supports for this research were obtained from the CGIAR Program on Wheat (WHEAT), the Arab Fund for Social and Economic Development (AFSED) Scholarship Fund and the project on Enhancing Food Security in Arab Countries - funded by AFESD, Kuwait Fund for Agricultural and Economic Development (KFAED), the Bill \& Melinda Gates Foundation, The OPEC Fund for International Development (OFID) and Islamic Development Fund (IsDB). 


\section{Compliance with ethical standards}

Conflict of interest The authors declare that they have no conflict of interest.

Open Access This article is distributed under the terms of the Creative Commons Attribution 4.0 International License (http:// creativecommons.org/licenses/by/4.0/), which permits unrestricted use, distribution, and reproduction in any medium, provided you give appropriate credit to the original author(s) and the source, provide a link to the Creative Commons license, and indicate if changes were made.

\section{References}

Affognon, H., C. Mutungi, P. Sanginga, \& C. Borgemeister. (2015). Unpacking Postharvest Losses in Sub-Saharan Africa: A MetaAnalysis. World Development, 66, 49-68. https://doi.org/10.1016/ j.worlddev.2014.08.002.

Al Rawi, M. 1989. Losses in crop grains during harvest and post-harvest. MSc Thesis, University of Jordan (in Arabic).

AOAD-Arab Organization for Agricultural Development. (2013). Arab food security situation report 2013. http://www.aoad.org/Arab\%20food\% 20security\%20report\%202013.asp. [Accessed on July 27, 2019].

Badran, I., A. Taimeh, H. Takruri, F. Abdullah, H. Bader, M. Khasawneh, G. Zreigat. 2018. Achieving SDG2 in Jordan. NCRD - The National Center for Research and Development. 2018.

Baloch, U. K. 1999. Wheat: Post- harvest operations. FAO/PARC. Islamabad. http://www.fao.org/fileadmin/user_upload/inpho/docs/ Post Harvest Compendium - WHEAT.pdf. [Last accessed on March 21, 2018].

Baloch, U.K., M. Irshad, and M. Ahmed. 1994. Loss assessment and loss prevention in wheat storage - technology development and transfer in Pakistan. Stored Product Protection. International Maize and Wheat Improvement Centre (CABI). England, UK.

Battesse, G. E., \& Coelli, T. J. (1995). A model for technical inefficiency effects in a stochastic frontier production function for panel data. Empirical Economics, 20, 325-332.

Beech, G. A., \& Crafts -Lighty, A. L. (1980). Energy use in flour production. Journal of the Science of Food and Agriculture, 31(3), 289-298.

Bellemare, M. F., Çakir, M., Peterson, H. H., Novak, L., \& Rudi, J. (2017). On the measurement of food waste. American Journal of Agricultural Economics, 99(5), 1148-1158.

Buzby, J. C., \& Hyman, J. (2012). Total and per capita value of food loss in the United State. Food Policy, 37(5), 561-570.

Clay, D.E., J. Chang, S.A. Clay, J. Stone, R. Gelderman, C.G. Carlson, K. Reitsma, M. Jones, L. Janssen, and T. Schumacher. 2012. Corn yields and notillage affects carbon sequestration and carbon footprints. Agron. J. 104, 763-770. https://doi.org/10.2134/agronj2011.0353.

Cuéllar, A. D., \& Webber, M. E. (2010). Wasted food, wasted energy: The embedded energy in food waste in the United States. Environmental Science \& Technology, 44(16), 6464-6469.

Duwayri, M. 2016. Rethinking food subsidy in Jordan. https://egyptssp. ifpri.info/2016/01/27/rethinking-food-subsidy-in-jordan/. [Accessed July 27 2019]

FAO- United Nations Food and Agricultural Organization. 2013. Wheat: Post- harvest Operations: http://www.fao.org/fileadmin/user upload/inpho/docs/Post_Harvest_Compendium___WHEAT.pdf [Accessed on April 4, 2018].

FMA - Flour Millers Association. 2016. Flour extraction and mill gain/ loss. https://www.facebook.com/permalink.php?story_fbid= 1629220044074160\&id=1513554368974062. [Accessed on July 27, 2019].

Food. 2009. Khubz Arabi (Pita or Flat Bread). https://www.food.com/ recipe/khubz-arabi-pita-or-flat-bread-348502. [Accessed on October 8, 2016].

Fox, T. and Fimeche, C. 2013. Global food waste not, want not. IMechE. England and Wales. https://www.imeche.org/policy-and-press/ reports/detail/global-food-waste-not-want-not. [Accessed December 14, 2017].

Goldsmith, P. D., Martins, A. G., \& de Moura, A. D. (2015). The economics of post-harvest loss: A case study of the new large soybean maize producers in tropical Brazil. Food Security, 7(4), 875-888.

Gustavsson, J., Cederberg, C., Sonesson, U., van Otterdijk, R., Meybeck, A, 2011. Global Food Losses and Food Waste: Extent Causes and Prevention. Rome, Food and Agriculture Organization (FAO) of United Nations. http://www.fao.org/docrep/014/mb060e/ mb060e00.pdf. [Last accessed on March 21, 2018].

Hanson, C., B. Lipinski, K. Robertson, D. Dias, I. Gavilan, P. Gréverath, S. Ritter, J. Fonseca, R. VanOtterdijk, T. Timmermans, J. Lomax, C. O'Connor, A. Dawe, R. Swannell, V. Berger, M. Reddy, D. Somogyi, B. Tran, B. Leach and T. Quested. 2016. Food loss and waste accounting and reporting standard. https:/www.wri.org/sites/default/ files/REP FLW_Standard.pdf. [Accessed on November 14, 207].

Hodges, R. J., Buzby, J. C., \& Bennett, B. (2011). Postharvest losses and waste in developed and less developed countries: Opportunities to improve resource use. Journal of Agricultural Science, 149, 37-45.

Hussain, I., R. Sakthivadivel, U. Amarasinghe, M. Mudasser and D. Molden. 2003. Land and water productivity of wheat in the western Indo-Gangetic plains of India and Pakistan: A comparative analysis. International Water Management Institute (IWMI) Research Report 65. Colombo, Sri Lanka.

JIEW - Jordan Independent Economy Watch. 2014. Restructuring subsidies: The socio-economic impact. http://identity-center.org/sites/ default/files/Restructuring\%20Subsidies-The\%20SocioEconomic\%20Impact.pdf [Accessed on Feb 10, 2019].

Jones, M. S., Alexander, C. E., \& Smith, B. (2018). Economic consequences of post-harvest insect damage in Rwandan common bean markets. Crop Protection, 104, 92-100.

Khraishy, M and M. J. Beillard. 2018. Jordan ends bread subsidies, implements USDA-Style SNAP EBT Program. USDA Foreign Agricultural Services, GAIN Report Number JO18001. https:// gain.fas.usda.gov/Recent\%20GAIN\%20Publications/Jordan\% 20Ends $\% 20$ Bread $\% 20$ Subsidies $\% 20$ and $\% 20$ Implements $\%$ 20USDA-Style\%20SNAP\%20EBT\%20Progr_Amman_Jordan_122-2018.pdf. [Accessed on May 19, 2019].

Kitinoja, L and A. A. Kader. 2015. Measuring postharvest losses of fresh fruits and vegetables in developing countries. The Postharvest Education Foundation (PEF) White Paper -15-02. http://postharvest. org/PEF White_Paper_15-02_PHFVmeasurement.pdf. [Accessed 6 Oct 2017]

Lipiniski, B. 2013. By the numbers: Reducing food loss and waste. World Resource Institute (WRI)'s blog series: "Creating a sustainable food future". https://www.wri.org/blog/2013/06/numbers-reducing-foodloss-and-waste [Accessed on February 6, 2019].

Lobell, D. B. (2013). The use of satellite data for crop yield gap analysis. Field Crops Research, 143, 56-64.

Montross, M. D., Maier, D. E., \& Hghighi, K. (2002). Development of a finite-element stored grain ecosystem model. Transactions of the ASAE, 45(5), 1455-1464.

Obeidat, Z., Obeidat M., \& Obeidat A. (2015). Wasteful consumption of bread: Its levels, sources, and possible solutions: A case study of Jordan. European Journal of Business and Management, 7(15), ht t p s://pdfs.semanticscholar.org/ 7 c $97 /$ 
7ccc27813ef07935ce5dbb563f5f859b0b5a.pdf [Accessed July 27, 2019].

Pardey, P. G. (2011). A strategic look at global wheat production productivity and R\&D developments. Czech Journal of Genetics and Plant Breeding, 47(special Issue), S6-S19.

Sattar, M., U-Din, M., Ali, M., Ali, L., Waqar, M. Q., Ali, M. A., \& Khalid, L. (2015). Grain losses of wheat as affected by different harvesting and threshing techniques. International Journal of Research in Agriculture and Forestry, 2(6), 20-26.

Sawhney, K. L. 1988. Post-harvest handling and storage of food grain in India. Proceedings of FAO Workshop on bulk storage of food grains. Hanzhu, China.

Seijaparova, D. and J. W. vH. Pellekaan. 2004. JORDAN an evaluation of World Bank assistance for poverty reduction, health and education: A country assistance evaluation. The World Bank, Washington D.C. http://documents.worldbank.org/curated/en/574041468752760085/ pdf/293660JordanCAE1Poverty.pdf. [Accessed on February 11, 2019].

Sidahmed, A. E., W. A. Rabboh, S. Khresat, E. Karablieh. 2012. Assessment of the agricultural sector in Jordan. Pre-identification mission: Support to agricultural development in Jordan. Contract $\mathrm{N}^{\circ}$ 2011/278635- version 1. EuropeAid/127054/C/SER/multi LOT $N^{\circ} 1$ : Rural development \& food security. http://moa.gov.jo/ Portals/0/studies/. [Accessed on February 11, 2019].

Snober, B., Duwayri, M., Haddad, N. And Tell, A.M. 1985. Harvesting and threshing losses in cereal and legume crops in Jordan. Dirasat. 12(4), 7-20.

Trostle, R. (2010). Global agricultural supply and demand: Factors contributing to the recent increase in food commodity prices/ WRS0801. Economic Research Service/USDA. https://www.ers.usda. gov/webdocs/publications/40463/12274_wrs0801_1_.pdf?v=0. [Accessed on July 27, 2019]

UN-DESA-United Nations, Department of Economic and Social Affairs, Population Division (2017). World population prospects: The 2017 revision, key findings and advance tables. ESA/P/WP/248. https:// esa.un.org/unpd/wpp/Publications/Files/WPP2017_KeyFindings. pdf. [Last accessed on April 22, 2018].

Verma M., 2015. Food wastage-Energy wasted. In: Energy use in global food production. Springer Briefs in Food, Health, and Nutrition. Springer, Cham.

WB - The World Bank, 2008. Double Jeopardy: responding to high food and fuel prices. http://siteresources.worldbank.org/INTPOVERTY/ Resources/335642-1210859591030/G8-HL-summit-paper.pdf. [Last accessed on April 19, 2018].

WHEAT - The CGIAR Program on Wheat. 2016. Wheat agri-food systems proposal- 2017-2022. http://wheat.org/phase-ii/ [Last accessed on February 15, 2017].

WHO - World Health Organization, 2014. Food security. Available from http://ww.who.in/trade/glossory/story028/en/Accessed 17.09.2014. [Last accessed on March 21, 2018].

Wilson, D. C., \& Wilson, L. (2009). The bread we waste the past, present and future for the world's wasted food. The Food Ethics Magazine, 4(3), 4-7.

Yigezu, Y. A., Aw-Hassan, A., Shideed, K., \& Al-Shatter, T. (2014). A policy option for valuing irrigation water in the dry areas. Water Policy, 16, 520-535.

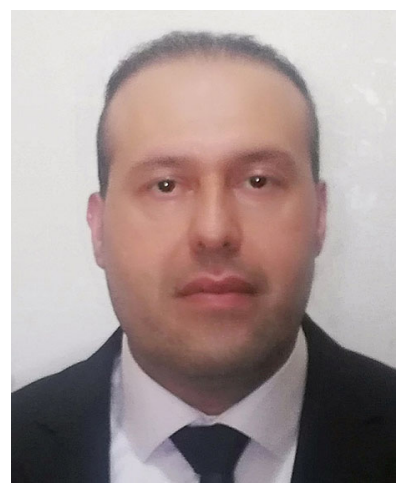

Basel F. Y. Khader Basel obtained his Ph.D. degree in Field Crops and Horticulture in 2017 and an MSc degree in plant protection (with distinction) in 2011 - both from the University of Jordan (UoJ), and a BSc (also with distinction) in plant production from Jordan University of Science and Technology (JUST) in 1994. The title of his Ph.D. dissertation is "Assessment of Pre and Postharvest Losses Along the Wheat Value Chain in Jordan". Since 2015, Basel has been working as head of the Department of Scientific Research Support Fund in the Jordanian Ministry of Higher Education (MHE), which is responsible for the evaluation of grant proposals for research in agricultural development in the country. Prior to joining MHE, Basel has worked in private agricultural enterprises holding different positions including one where he was the Manager of an enterprise. Basel also served as a university lecturer.

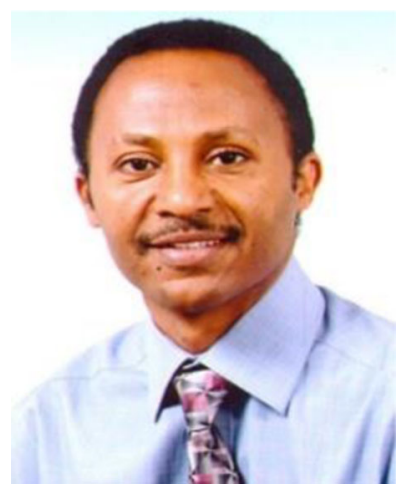

Yigezu A. Yigezu Yigezu is an agricultural economist with a focus on international development and policy analysis. He has research experience in various areas of agricultural development including: production economics, bio-economic modeling of production systems, natural resource and environmental economics, livestock value chain analysis, policy analysis, and technology adoption, out-scaling and impact assessment. Yigezu's quantitative skills include: mathematical programming, stochastic dynamic programming, computable general equilibrium (CGE) and input-output (IO) modeling and Econometrics. Yigezu earned his MSc (2005) and PhD (2009) degrees in Agricultural Economics from Purdue University, U.S.A. and has two bachelor's degrees. Since 2010, he has been working with the International Center for Agricultural Research in the Dry Areas (ICARDA) as a postdoc (2010), Agricultural Economist (2011-2012) and as a Senior Agricultural Economist since 2012. Prior to his graduate studies, Yigezu has also worked for over 14 years with several governmental and nongovernmental development, humanitarian, and research organizations. Dr. Yigezu is currently based in Amman, Jordan. 


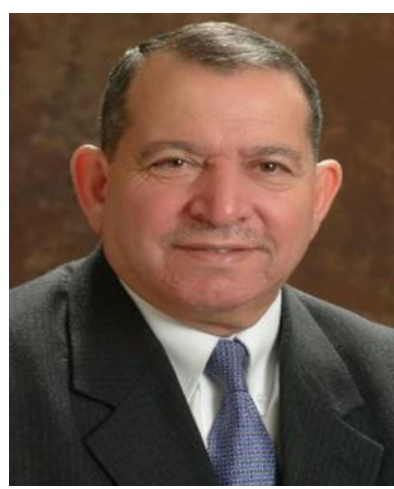

Mahmud A. Duwayri Dr. Mahmud Duwayri joined the University of Jordan in 1973 after his graduation with a $\mathrm{PhD}$ in plant breeding and Genetics from the University of Wisconsin, USA. During his career, he served the agriculture and education sectors in Jordan, the region, and the globe. He worked as dean of agriculture at the University of Jordan and the United Arab Emirates, vice president at the Jordan University for Science and Technology and President of Ajloun National University. During his tenure with the universities, his work included supervision of several masters and $\mathrm{PhD}$ students in the areas of agronomy, plant breeding and food security. Later, he was also appointed Director General of the National Agricultural Research Center in Jordan and this was followed by his appointment as Director of the Plant Production and Protection Division of the Food and Agriculture Organization (FAO) of the United Nations based in Rome (1998-2001). In June 2001, he was appointed Minister of Agriculture of Jordan. He also served on several International boards and committees. Presently he is a board member of several educational and agricultural Institutions and is a consultant on issues of food security and agricultural sustainability.

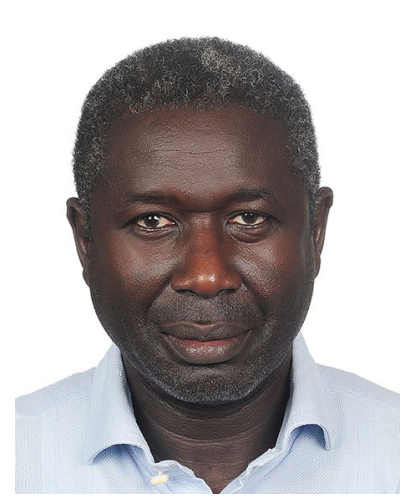

Abdul Aziz Niane Dr. Abdoul Aziz Niane earned his PhD in range land ecology in 2013 from the Netherlands, an MSc in plant protection in 1992 from Cucurova University, Turkey and a BSc in Plant protection in 1986 from Aleppo University, Syria. Dr. Niane is currently a Scientist specializing in seed technology with the Biodiversity and Crop Improvement Program of the International Center for Agricultural Research in the Dry Areas (ICARDA) where he has worked since 1987. Dr. Niane is based in Beirut, Lebanon.

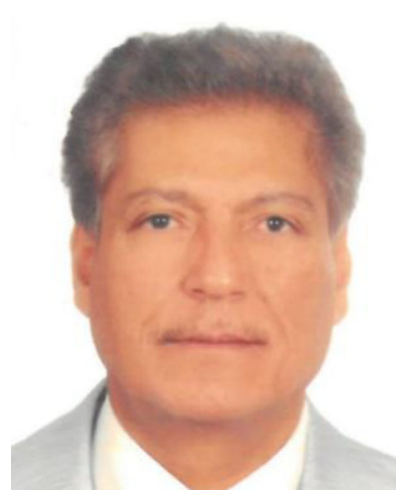

Kamil Shideed Dr. Kamel Shideed is currently ICARDA's Assistant Director General for International Cooperation and Communications - a position, which he has held since 2009 . Prior to that and starting in 2005, he was the Director of ICARDA's Social, Economic and Policy Research Program after serving at ICARDA as a senior Natural Resources Economist since 2004. Before joining ICARDA, Dr. Shideed was Head of Planning and Economic Analysis at the Agricultural Research System and Professor at the University of Baghdad in Iraq. He served as a Senior Research Fellow at the Agricultural Economics Department, University of Georgia in USA during 1985-1989, with a research focus on production economics and policy research. Dr. Shideed has a wide range of experience including international agricultural research-for-development, resource mobilization and donor's relations, project design and implementation, and partnerships. He has active networks with partners in many developed and developing countries, particularly in West Asia, North Africa, Nile Valley and SubSaharan Africa, South Asia, and Central Asia and the Caucasus regions. Dr. Shideed received a PhD from Mississippi State University, USA in 1984 in Agricultural Economics. He has authored and co-authored over 130 publications. 